\title{
Tourists' willingness to pay to view otters along the Wild Coast, South Africa: a potential for in- creased ecotourism
}

\author{
Lihle Dumalisile, Michael Somers, Michele Walters \& Jan NeL
}

\begin{abstract}
This article reports on tourists' willingness to pay to view Cape clawless otters Aonyx capensis along the Eastern Cape Wild Coast, South Africa. We collected data from a survey carried out using a structured, selfadministered questionnaire. We analyzed 67 completed questionnaires, of which 60 respondents $(89.5 \%)$ indicated that they would be interested in viewing otters and would be prepared to pay an extra fee, over and above the normal entrance fees, for a trained guide to show them otters. The remaining $7(10.4 \%)$ respondents indicated that they would reconsider and pay if this would create jobs for members of the local community. Most $(98.4 \%$ and $91.8 \%$ ) of the respondents also indicated that they would still pay even if there was only a $50 \%$ or $25 \%$ chance of seeing otters. Most of the respondents were willing to pay either less than R50.00 (ca US\$8.00) or R50.00R100.00 to view otters regardless of the chances of seeing them. We conclude from our results that otters do have the potential to increase ecotourism in the area, and also to contribute financially to the poverty stricken local Dwesa community.
\end{abstract}

Keywords. Aonyx capensis, Cape clawless otter, small carnivores, rural development.

\section{Introduction}

Visiting areas of natural beauty, or ecotourism, is gaining popularity in many countries around the world (Gössling 1999; Kepe 2001), and is assumed by some to provide a mechanism for the maintenance of biodiversity (Miller et al. 1995). For instance, in Gauteng Province, ecotourism has replaced hunting as the primary revenue earner for the majority of game farms (Reilly et al. 2003). In South Africa tourism has been seen as a potential driving force behind national economic development and also as a catalyst for job creation (Rogerson 2002). As effective job creation remains perhaps the most elusive objective of the South African government further expansion of the tourism industry is being actively pro-

1 Lihle Dumalisile, Michael Somer and Michele Walters are are attached to the Applied Behaviour and Ecology Laboratory, Centre for Invasion Biology, Department of Zoology, Walter Sisulu University, Private Bag X1, 5117 UNITRA, South Africa. Jan A.J. $\mathrm{Nel}$ is attached to the Department of Zoology and Botany, University of Stellenbosch, Private Bag X1, 7602 Matieland, South Africa. All correspondence should be addressed to Michael Somer at michaelsomers@yahoo.com. 
moted by all (Mahony \& van Zyl 2002).

Small carnivores are shy and secretive in behaviour. As a result, they have often been overlooked in biodiversity and conservation management studies. As the economic impact (real or perceived) of wildlife has a strong influence on people's attitudes towards conservation (Infield 1988), it is unfortunate that small carnivores are often overlooked from an economic perspective. Large carnivores, on the other hand, are frequently the main focus when it comes to carnivore conservation, with the rationale being that carnivores are renaissance taxa, involving a synthesis of conservation problems, causal factors and solutions (Gittleman et al. 2001) and that protection of other taxa in lower trophic levels is assured. Small carnivores can be popular with the general public but are just seldom seen and therefore not appreciated. By virtue of their popularity with the public (White et al. 1997; 2001) otters are ideal targets for conservation strategies based on financial incentives from ecotourism.

Cape clawless otters Aonyx capensis are widely distributed in sub-Saharan Africa (Rowe-Rowe \& Somers 1998; Nel \& Somers 2002) and occur mainly in freshwater habitats such as rivers, marshes, lakes and dams where they eat predominantly freshwater crabs Potamonautes spp. They also occur in marine habitats where there is fresh water nearby (Van Niekerk et al. 1998). Cape clawless otters usually feed alone but they may occur in groups of up to five (Rowe-Rowe 1978; Arden-Clarke 1983; Somers 2000a). They are specialized crab eaters, but also feed on fish, frogs, insects and occasionally birds (waterfowl) and small mammals, such as shrews and rodents (reviewed in Rowe-Rowe \& Somers 1998). In marine habitats they eat mostly fish followed first by crabs, then by octopus or lobster (Van der Zee 1979, 1981; Arden-Clarke 1983; Verwoerd 1987; Somers $2000 a, b)$. Cape clawless otters are typically active from dawn for $2.6 \mathrm{~h}$ and from sunset for a mean of $2.3 \mathrm{~h}$ (Somers \& Nel 2004). During the heat of the day they rest in dry places, in holes in the ground, under rocks, in sheltered places in erosion gullies or in dense reed beds adjacent to their habitat (Somers 2001). The pattern of female home ranges suggests territoriality. Males have overlapping home ranges, both with other males and females (Somers $\&$ Nel 2004). In fresh water, total home range length varies from 4.9 to $54.1 \mathrm{~km}$. The total area of water used ranges from 4.9 to 1062.5 ha (Somers $\&$ Nel 2004). In a marine habitat home range varies from 5.4 to $19.5 \mathrm{~km}$ of coast (Arden-Clarke 1986).

The research, conducted for the purposes of this study, was aimed at determining whether tourists at Dwesa Nature Reserve on the coast of the Eastern Cape Province were interested in seeing otters and whether they were willing to pay to do so. This was done through a questionnaire survey directed at tourists visiting this reserve. 


\section{Study area and methods}

Sampling was done in Dwesa Nature Reserve, which is situated on the Eastern Cape Wild Coast in South Africa between $32^{\circ} 12^{\prime}-32^{\circ} 20^{\prime} \mathrm{S}$ and $28^{\circ} 48^{\prime}-28^{\circ} 58^{\prime} \mathrm{E}$ (McKenzie 1979). The reserve is ca 3900 ha in size and is contiguous with Cwebe Nature Reserve (2140 ha) to the north. Vegetation types are mainly Coastal Forest, Thornveld and Valley Bushveld (Acocks 1988). The area has a warm temperate climate with the coldest months being between $-3^{\circ} \mathrm{C}$ and $18^{\circ} \mathrm{C}$ and the warmest months below $22^{\circ} \mathrm{C}$, but at least four months above $10^{\circ} \mathrm{C}$. Annual precipitation is $875 \mathrm{~mm}$, falling between September and January with the dry season lasting from May to August, with approximately $35-40 \mathrm{~mm}$ falling in each of these months (McKenzie 1979).

A survey procedure was used to assess if tourists at Dwesa would be interested in seeing otters and, furthermore, if they would be willing to pay a trained guide to show them otters. To give the respondents the opportunity to complete the questionnaires in their own time, the survey was done by way of a structured, self-administered questionnaire. A total of 120 questionnaires were handed out to tourists between July and October 2004. Tourists were presented with the questionnaires upon their arrival at Dwesa and asked to fill them in and return them to the reception desk when finished. The questionnaire contained a brief introduction stating who was administering it, what the aim was and that the information may be used by management for future planning. There were 30 questions which consisted of different structured questions including open questions, closed questions and rank ordering questions. Some of the questions were personal (such as gender, age, nationality, residency, level of education, income, reasons for visiting Dwesa).

A Chi square $\left(\mathrm{x}^{2}\right)$ test was used to test for independence between nationality (South African vs. non-South African) of the respondents and willingness to pay a trained guide to show them otters, and also between the respondents' knowledge of otters and their willingness to pay.

\section{Results}

We received 67 completed questionnaires. Many of the respondents did not respond to personal questions such as age, gender, residency, level of education and income. Responses to some of the questions are provided in Table $1 .{ }^{2}$ Six $(9.0 \%)$ respondents were not interested in paying a trained guide to show them otters and one (1.5\%) was undecided. All the respondents that were initially uninterested in paying and the one that was undecided indicated that they would reconsider and pay if it meant employment of members of the Dwesa community.

Nationality and willingness to pay a trained guard were independent of

2. See Table at the end of this text. 
each other $\left(\mathrm{x}^{2}=2.67 \mathrm{df}=1, P=0.10\right)$ as was the respondent's knowledge of otters and their willingness to pay $\left(\mathrm{x}^{2}=0.30 \mathrm{df}=1, P=0.58\right)$.

Most of the respondents were willing to pay either less than R50.00 (ca US\$8.00) or R50.00-R100.00 to view otters regardless of the chances of seeing them. We found that the number of respondents that would pay less than R50.00 to view otters, increased as the percentage chance of seeing otters decreased, while the number of respondents that would pay R50.00-R100.00 to view otters decreased as the percentage chances decreased (Fig. 1). Five (8.3\%) respondents indicated that they would pay R100-R150 for both $100 \%$ and $50 \%$ chances of seeing otters and $1(1.8 \%)$ would pay the same amount for $25 \%$ chances of seeing otters. None of the respondents would pay R150-R200 to view otters, while only one (1.7\%) would pay more than R200 for all chances of seeing otters (Fig. 1).

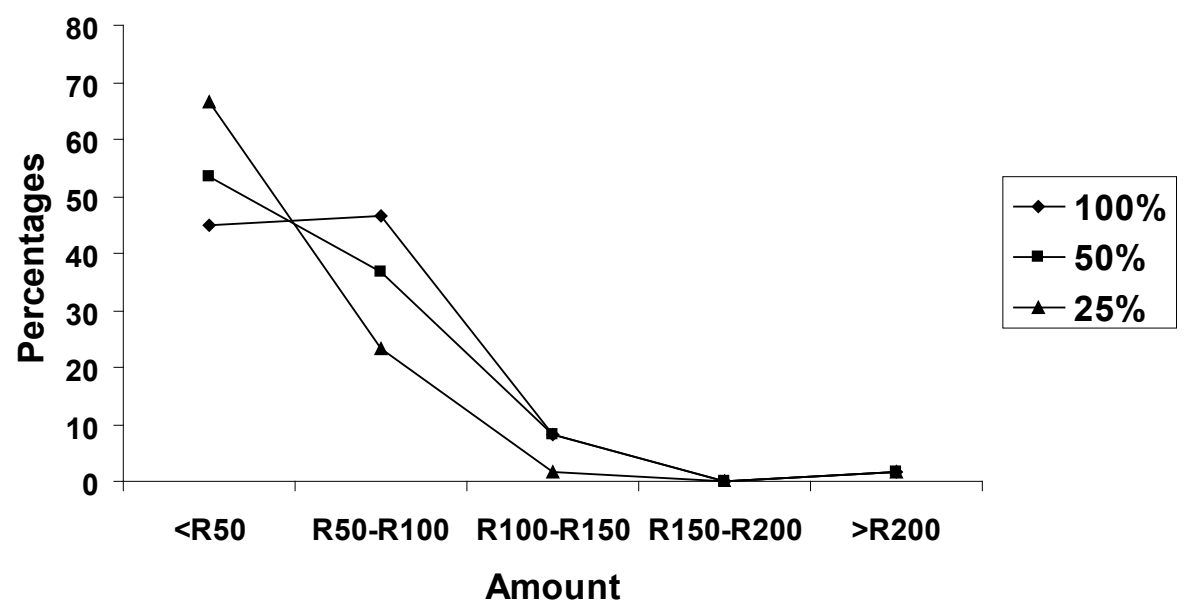

Figure 1. The willingness to pay varying amounts for different chances of seeing Cape clawless otters Aonyx capensis in Dwesa Nature Reserve.

\section{Discussion}

The most striking result is that almost all tourists to Dwesa Nature Reserve wanted to view otters and were willing to pay to do this. Also those respondents who showed no interest in paying a trained guide to show them otters, indicated that they would reconsider and pay that would create employment opportunities for members of the Dwesa community. Considering the percentage of tourists willing to pay to view the rare and endangered African wild dog Lycaon pictus in four large South African reserves namely Kruger National Park (73.4\%), Pilanesberg National Park 
(78.9\%), Djuma Game Reserve (52.3\%), and Ngala Game Reserve (65\%) (Lindsey et al. 2005), otters appear to be highly rated as a species to view. However the amount (\$12.00-\$59.00) (Lindsey et al. 2005) tourists are willing to pay to view wild dogs was greater than for otters.

Unexpectedly we found that the number of respondents that would pay less than R50.00 to view otters increased as the percentage chance of seeing otters decreased. This we consider a result of our small sample size and as expected the number of respondents that would pay R50.00R100.00 to view otters decreased as the percentage chances decreased. There were no unexpected results from comparing the willingness to pay and gender, age and residency of the respondents. It was expected that with some knowledge would come a greater desire to see otters. Our results did not show this. This is perhaps due to us not specifying the source of knowledge (that is whether in the wild, on television, in a picture or otherwise). Also unexpectedly the nationality of the respondents and their willingness to pay shows that nationality and the willingness to pay were not related. The reason for these two findings may simply be that almost all were willing to pay. As expected non-South Africans were willing to pay more than South Africans for such a unique experience.

Guiding offers opportunities to expand community involvement, through employment of game guides, and environmental education components of ecotourism with the quality of wildlife viewing possibly significantly improved through the use of guides (Kerley et al. 2003). We propose that the ease with which otters can be viewed at Dwesa be investigated and appropriate arrangements made to train guides to observe the otters in the present study area. At Kogel Bay in False Bay (Western Cape Province, South Africa) it is possible, with some training, to view otters on $30 \%$ of visits (Somers 2000a). We predict a similar or better chance of seeing otters along the pristine Eastern Cape Wild Coast. As many tourists are willing to pay R50.00 or more to view otters, a steady income for at least one trained guide at each suitable reserve along the Wild Coast (and perhaps elsewhere) is attainable. This would involve ca three hours of work in the early morning to catch the ca 2.6 hours of otter activity (Somers \& Nel 2004). Seeing otters during the nocturnal activity bout is not considered feasible. Also, most of the respondents visited Dwesa for holiday or some other nature based activities such as fishing, sightseeing or bird watching. We propose that watching otters or other taxa besides birds should be encouraged and actively promoted. We conclude from our results that otters do have the potential to increase ecotourism in the area, and also to contribute financially to the poverty stricken local Dwesa community, and possibly other communities along the Wild Coast.

Finally it is essential to be realistic about the impacts of tourism investment on the rural development and economic growth (Mahony \& van Zyl 2002). Local tourism initiatives may contribute to addressing local socioeconomic needs; but they have limited impacts on a macro scale (Mahony 
\& van Zyl 2002). We therefore do not propose otter ecotourism to be a solution to the greater problem of poverty but only a small contribution.

\section{Acknowledgements}

We thank all those members of the public who completed our questionnaire. Mandisa Mgobozi is thanked for assistance in the field. We thank the staff at Dwesa Nature Reserve for permission to do the work and for distributing the questionnaires. Markus Gusset is thanked for useful comments on the manuscript. We thank the National Research Foundation (LD, MJS, MW JAJN) and DST-NRF Centre of Excellence for invasion Biology (MJS) for funding. 
Table 1. Results of a questionnaire to determine willing to pay to view Cape clawless otters Aonyx capensis at Dwesa Nature Reserve. Values outside parentheses refer to number of respondents and values inside parentheses refer to percentages.

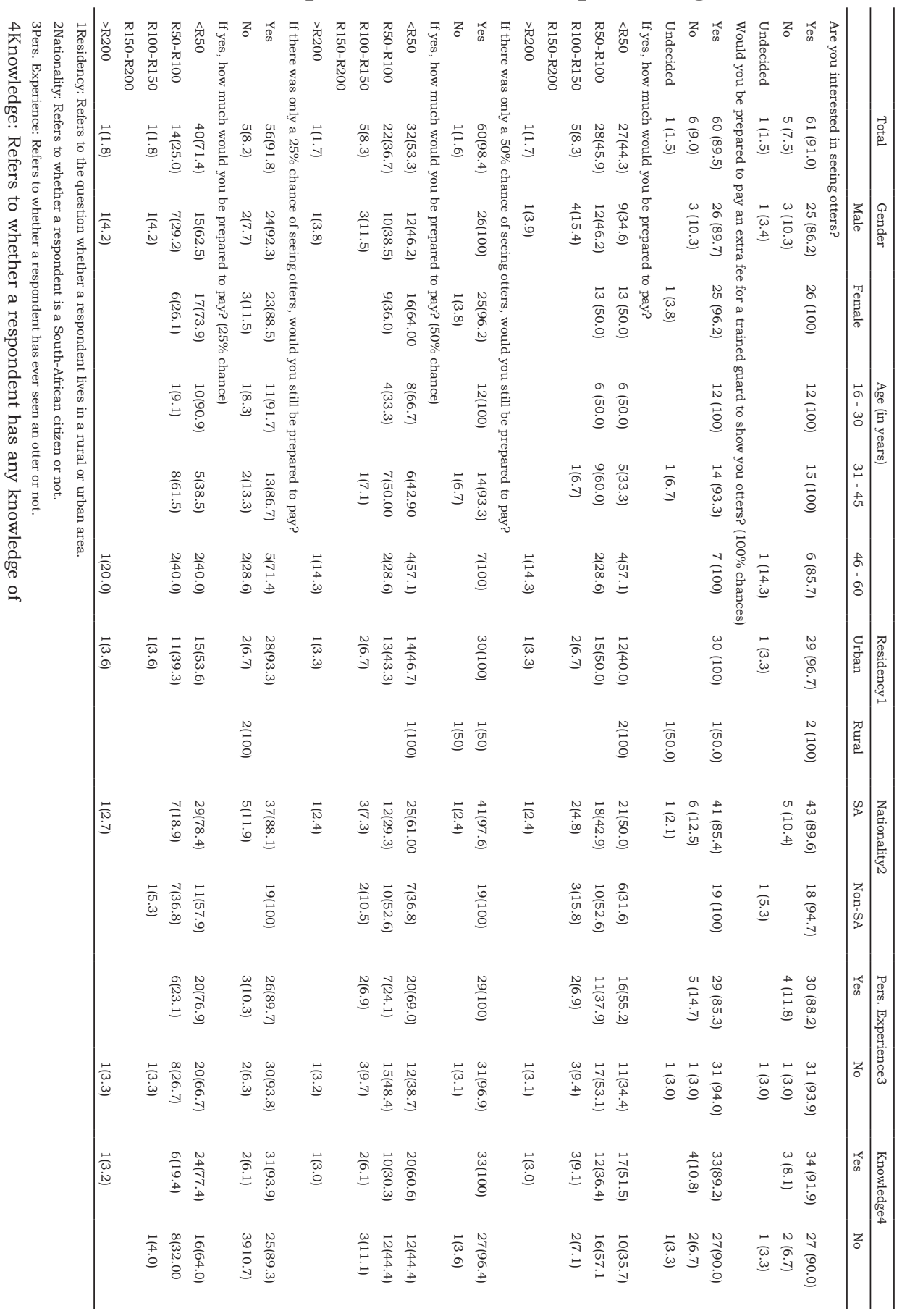




\section{References}

ACOCKS, J.P.H. 1988. Veld Types of Southern Africa. Mem. bot. Surv. S. Afr. 57: 1-128.

ARDEN-CLARKE, C.H.G. 1983. Population density and social organisation of the Cape clawless otter, Aonyx capensis Schinz, in the Tsitsikama Coastal National Park. M.Sc. thesis, University of Pretoria, Pretoria, South Africa.

ARDEN-CLARKE, C.H.G. 1986. Population density, home range size and spatial organization of the Cape clawless otter, Aonyx capensis, in a marine habitat. J. Zool., Lond. 209: 201-211.

GITTLEMAN, J.L., FUNK, S.M., MACDONALD, D.W. \&. WAYNE, R.K. 2001. Why 'carnivore conservation'? In: J.L. Gittleman, S.M. Funk, D.W. Macdonald \&. R.K. Wayne (Eds.), Carnivore conservation (pp. 1-8). Cambridge University Press, Cambridge.

GÖSSLING, S. 1999. Ecotourism: a means to safeguard biodiversity and ecosystem functions? Ecol. Econ. 29: 303-320.

INFIELD, M., 1988. Attitudes of a rural community towards conservation and a local conservation area in Natal, South Africa. Biol. Conserv. 45: 21-46.

KEPE, T. 2001. Tourism, protected areas and development in South Africa: views of visitors to Mkambati Nature Reserve. S. Afr. J. Wildl. Res. 31: 155-159.

KERLEY, G.I.H., GEACH, B.G.S. \& VIAL, C. 2003. Jumbos or bust: do tourists' perceptions lead to an under-appreciation of biodiversity? S. Afr. J. Wildl. Res. 33: 13-21.

LINDSEY, P., ALEXANDER, R.R., DU TOIT, J.T. \& MILLS, M.G.L. 2005. The potential contribution of ecotourism to African wild dog Lycaon pictus conservation in South Africa. Biol. Conserv. 123: 339-348.

MAHONY, K. \& VAN ZYL, J. 2002. The impacts of tourism investment on rural communities: three case studies in South Africa. Dev. Sth. Afr. 19: 83-102.

MCKENZIE, B. 1979. The grasslands of the Dwesa Nature Reserve. Habitat Working Group Report, University of Cape Town.

MilleR, K., ALlEGRETTI, M.H., JOHNSON, N. \& JONSSON, B. 1995. Measures for conservation of biodiversity and sustainable use of its components. In: V.H. Heywood (Ed.), Global biodiversity assessment (pp. 915-1061). United Nations Environment Programme, Cambridge University Press, Cambridge.

NEL, J.A.J \& SOMERS, M.J. 2002. The status of otters in Africa: an assessment. In: R. Dulfer, J. Conroy, J.A.J. Nel, \& A.C. Gutleb, (Eds.) 
Otter conservation - an example for a sustainable use of wetlands. Proceedings of the VIIth International Otter Symposium IUCN Otter Specialist Group Bulletin Vol. 19A (Special Issue): 258-266.

REILLY, B.K., SUTHERLAND, E.A. \& HARLEY, V. 2003. The nature and extent of wildlife ranching in Gauteng Province, South Africa. $S$. Afr. J. Wildl. Res. 33: 141-144.

ROGERSON, C.M. 2002. Tourism and local economic development: the case of the Highlands Meander. Dev. Sth. Afr. 19: 143-167.

ROWE-ROWE, D.T. 1978. The small carnivores of Natal. Lammergeyer 25: $1-48$.

ROWE-ROWE, D.T. \& SOMERS, M.J. 1998. Diet, foraging behaviour and coexistence of African otters and the water mongoose. Symp. Zool. Soc. Lond. 71: 215-227.

SOMERS, M.J. 2000a. Foraging behaviour of Cape clawless otters (Aonyx capensis) in a marine habitat. J. Zool., Lond. 252: 473-480.

SOMERS, M.J. 2000b. Seasonal variation in the diet of Cape clawless otters (Aonyx capensis) in a marine habitat. Afr. Zool. 35: 261-268.

SOMERS, M.J. 2001. Habitat utilization of Cape clawless otters, Aonyx capensis. Ph.D. thesis, University of Stellenbosch, Stellenbosch, South Africa.

SOMERS, M.J. \& NEL, J.A.J. 2004. Movement patterns and home ranges of Cape clawless otters (Aonyx capensis), affected by high food density patches. J. Zool., Lond. 262: 91-98.

VAN DER ZEE, D. 1979. Food and status of the Cape clawless otter, Aonyx capensis Schinz, in the Tsitsikama Coastal National Park. M.Sc. thesis. University of Pretoria, Pretoria, South Africa.

VAN DER ZEE, D. 1981. Prey of the Cape clawless otter (Aonyx capensis) in the Tsitsikama Coastal National Park, South Africa. J. Zool., Lond. 194: 467-483.

VAN NIEKERK, C.H., SOMERS, M.J. \& NEL, J.A.J. 1998. Freshwater availability and distribution of Cape clawless otter spraints and resting places along the south-west coast of South Africa. S. Afr. J. Wildl. Res. 28: 68-72.

VERWOERD, D.J. 1987. Observations on the food and status of the Cape clawless otter Aonyx capensis at Betty's Bay, South Africa. S. Afr. J. Zool. 22: 33-39.

WHITE, P.C.L., BENNETT, A.C. \& HAYES, E.J.V. 2001. The use of willingness-to-pay approaches in mammal conservation. Mammal. Rev. 31: 151-167. 
Dumalisile, Somers, Walters \& Nel

WHITE, P.C.L., GREGORY, K.W., LINDLEY, P.J. \& RICHARDS, G. 1997. Economic values of threatened mammals in Britain: A case study of the otter Lutra lutra and the water vole Arvicola terrestris. Biol. Conserv. 82: 345-354. 